Annals of Warsaw University of Life Sciences - SGGW

Land Reclamation No 48 (2), 2016: 123-139

(Ann. Warsaw Univ. Life Sci. - SGGW, Land Reclam. 48 (2), 2016)

\title{
Assessment of the effect of rainfall dynamics on the storm overflow performance
}

\author{
BARTOSZ SZELĄG
}

Faculty of Environmental, Geomatic and Energy Engineering, Kielce University of Technology

\begin{abstract}
Assessment of the effect of rainfall dynamics on the storm overflow performance. This research study analyzes the effect of the rainfall characteristics (total and maximum 10-, 15- and 30-minute rainfall depth, its duration, the dry weather period) on the performance of the emergency overflow weir located at the inflow to an existing treatment plant. The analyses used the numerical calculation results of the inflow hydrographs performed in the SWMM (Storm Water Management Model) program on the basis of six-year-long rainfall measurement sequence. The obtained simulation results for the analysed catchment allowed for the performance of statistical analyses, which demonstrated that the volume of stormwater discharge, the maximum instantaneous flow and the share of stormwater volume discharged through the emergency overflow weir in relation to the total volume of the inflow hydrograph from the catchment are affected by the maximum 30-minute rainfall depth, whereas the discharge duration is affected by the depth of the catchment rainfall layer. Taking into account the results of statistical and hydraulic calculations it can be concluded that in the case of the analysed catchment the performance of the emergency overflow weir is affected to the greatest extent by the rainfall intensity distribution.
\end{abstract}

Key words: SWMM, continuous simulation, overflow discharge, stormwater treatment plant

\section{INTRODUCTION}

The negative effect of stormwater on the receiver (reservoirs and rivers being silted up and biological-chemical processes disturbed) continues to be an important scientific and research problem of our times, as is confirmed by numerous studies in this field (Deletic 1998, Garbarczyk and Tuz 2003, Dąbrowski 2004, Paola and Martino 2013). Stormwater purification is the simplest method of reducing its adverse impact on the receiver.

Since runoffs vary significantly in time and are short-lasting, it is not economically and technologically reasonable to treat the whole volume of stormwater, but merely the part that is most polluted in the surface runoff (ATV DVWK A-128, Bertrand-Krajewski et al. 1998, Deletic 1998, Fidala-Szope 1999, Dąbrowski 2007, Bach et al. 2010, Czemiel-Berndtsson 2013). The remaining portion of stormwater volume is discharged directly into the receiver through the overflow.

Sequential measurement results of flows and rainfalls are a reliable and representative source of information on the performance of sewer system devices. They provide a basis for determining the regression relations used to calculate the volume of rainwater flooding the area, the volume of storm overflow discharges, as well as the frequency of those phenomena in the analysed period of time (Fidala Szope et al. 1999, Thorndahl 2008). 
The performance of the facilities located in the sewer system can be evaluated by means of regression models. They provide a solution which is an alternative to hydrodynamic models and allows considerable reduction in computational effort. In addition, these relations can be used at the level of the daily sewage system operation, without the necessity to implement numerical algorithms depicting the surface runoff and the sewage flow along the sewer network.

The performance of storm overflows located in sewage systems was studied by Vaes and Berlamont (1999) and also Zawilski et al. (2014). The conducted research revealed in both cases a linear relationship between a total rainfall depth, its duration and the volume of storm overflow discharge.

The literature review shows that the effect of the rainfall dynamics on the performance of an emergency overflow weir located at the inflow to the stormwater treatment plant has hitherto not been analysed with regard to determining the regression relations. Moreover, while focusing on the volume of the stormwater discharged through the overflow weir, the research disregarded other parameters connected with its operation, such as the duration of the discharge, the maximum instantaneous flow, or the separation of the stormwater volume discharged through the overflow weir from that flowing into the treatment plant. Those parameters have a considerable ecological significance, since what is very important in these circumstances, apart from the stormwater amount, the pollution concentration and thus the load of the inflowing contaminants, is the time of the stormwa- ter's exposure to the living organisms (Newcombe and Jensen 1996). The values of the maximum instantaneous flows discharged through the overflow allows for the assessment of the effect that a rainfall event has on the water condition in the receiver, while the percentage of the stormwater discharged through the overflow in relation to the total hydrograph volume provides the information on the loads that the technological structures are subject to.

Since multiannual flow measurements are costly, the evaluation of the overflow performance involves the use of numerical programs (SWMM, PCSWMM, MIKE URBAN, MOUSE), as well as simplified mathematical models (Dempsey et al. 1997, Vaes and Berlamont et al. 1999), which allow forecasting the sewer network performance based on the data of the catchment land use, topographical features, the arrangement of the sewer system, the diameters, gradients and roughness coefficients of the pipeline segments or the values of local head loss in manholes. These programmes allow to take into account the direction and velocity of the precipitation front movement across the catchments and the nonuniformity of the rainfall distribution over the catchment area. In the case of extended systems these are significant parameters since they affect the surface runoff, and thus the performance of the sewer network and the objects included therein.

It can be concluded from the reviewed literature, that the SWMM (Storm Water Management Model) is commonly used for the evaluation of the performance of sewer systems with reservoirs, storm overflows, facilities for capturing rainfall 
when still on the surface of the catchment (infiltration trenches, evaporating reservoirs, green roofs etc.). It results primarily from the possibility of adapting the source code of the program written in the $\mathrm{C}++$ programming language for one's own needs through its modification. Moreover, it should be stressed, that the SWMM has been successfully used for modelling the performance of separators (Mrowiec 2009), green roofs (Krebs et al. 2013), infiltration trenches and treatment plants (Szeląg et al. 2013).

Regardless of the applied model, the identification of the model parameters requires high resolution measurements of rainfall (Zaghloul and Kiefa 2001, Madsen 2003, Zawilski et al. 2014), and the investigation of the variability of stormwater flow and its quality in the cross-section closing an analysed catchment. The lack of this information prevents these programmes from performing an appropriate forecast of the surface runoff volume and the quality of stormwater (the load of contaminants). What should be noted here is that according to the findings of Mrowiec (2009), Skotnicki and Sowiński (2009), Zawilski (2010), several measured events of the rainfall-runoff type are enough to calibrate and validate hydrodynamic models. However, since rainfalls occur randomly and there is a possibility of errors during the measurements, the period should not be shorter than two years.

With multiannual observational sequences of rainfalls, it is possible to perform simulations allowing the application of the obtained calculation results to assess the frequency of discharges through storm overflows and through emergency spillways of detention reservoirs (Vaes and Berlamont 1999, Andrés-Doménech and Segura 2008, Cambez et al. 2008).

Bearing the above in mind, the paper refers to six-year-long precipitation measurement sequences obtained from a pluviometric station located in the area of the city of Kielce. The sequences were applied to simulate the performance of a storm overflow located on the inflow to the treatment plant, using the SWMM (Storm Water Management Model) program. On the basis of the results obtained for the analyzed catchment it was attempted to determine a relationship between the rainfall dynamics (the total rainfall depth, maximum 10-, 15- and 30-minute rainfall depth, the duration of the rainfall, the dry weather period), and the volume and duration time of the discharge, and also the maximum instantaneous flow discharged through the storm overflow. Three-year-long precipitation sequences from the raingauge station Suków, located $10 \mathrm{~km}$ from the border of the analysed catchment, were applied to validate the obtained relations.

\section{MATERIAL AND METHODS}

\section{Characteristics of the object of the study}

The paper analyzes the Si9 sewer catchment with the area of $F=62$ ha located in the central-eastern part of the city of Kielce. A detailed characteristics of the catchment can be found in the works of Dąbkowski et al. (2010) and Szeląg et al. (2013). The stormwater leaving the catchment through the storm drain Si9 (1) is directed to the division chamber 
(2), from where it gets to the treatment plant consisting of a rectangular horizontal settling basin (3), coalescence separator (4) and a control chamber (5) - Figure 1 . In the case of the chamber being filled to a depth of less than $0.42 \mathrm{~m}$, the stormwater flows through four pipes of $\varnothing=400 \mathrm{~mm}(i=0.0040, L=5.5 \div 8.1 \mathrm{~m})$ to a settling basin with the length of $30 \mathrm{~m}$ and the width of $7.2 \mathrm{~m}$. The sedimentation part of the basin is $1.65 \mathrm{~m}$ deep. In the case of the division chamber being filled to a depth exceeding $0.42 \mathrm{~m}$, the stormwater is directed to the discharge canal through the storm overflow with the edge length of $2.5 \mathrm{~m}$ and a variable width (Fig. 2). The stormwater from the rectangular settling basin flows si- multaneously: to the separator through the pipe of $\varnothing=200 \mathrm{~mm}(i=0.0050$; $L=2.6 \mathrm{~m}$ ), and to the control chamber through two pipelines of $\varnothing=500 \mathrm{~mm}$ $(i=0.002 ; L=3.6 \div 7.2 \mathrm{~m})$. The chamber also receives the stormwater outflowing through the pipe of $\varnothing=350 \mathrm{~mm}$ $(i=0.002, L=3 \mathrm{~m})$ from the coalescence separator. From the control chamber the stormwater flows through the pipeline of $\varnothing=600 \mathrm{~mm}(i=0.0025, L=60 \mathrm{~m})$ to the receiver, i.e. the Silnica river.

Three metres from the storm drain Si9 outlet to the division chamber there is an ultrasonic flow meter installed in the drain, and about $2 \mathrm{~km}$ from the northern border of the catchment there is a raingauge station. The division cham-

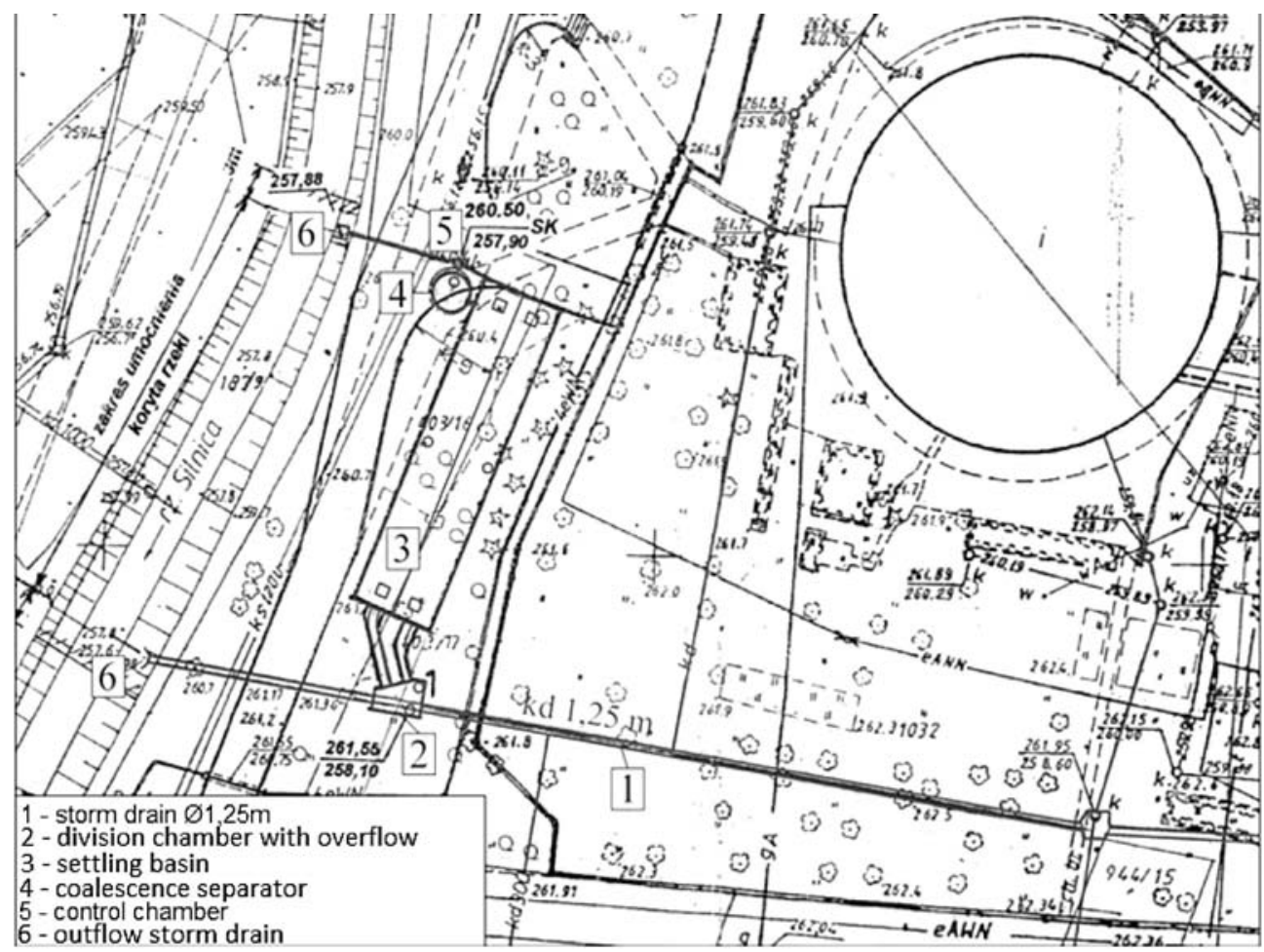

FIGURE 1. Stormwater treatment plant at the IX Wieków Kielc avenue (Butech 2003) 


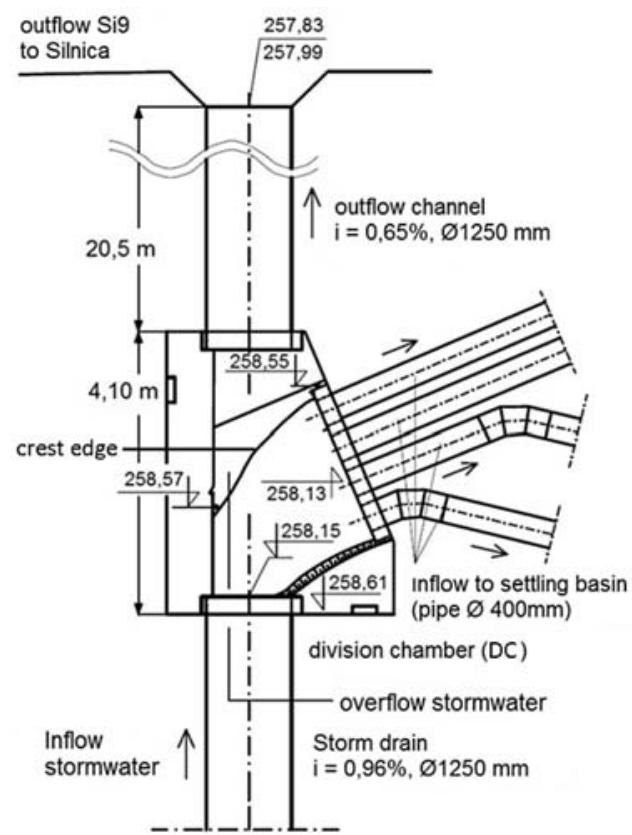

FIGURE 2. Operational diagram of the division chamber

ber is equipped with a sampler that is additionally fitted with a sensor for measuring the filling level, triggering the stormwater sampling for the determination of heavy metals and total suspended solids (Bąk et al. 2012).

\section{Precipitation data}

The evaluation of the stormwater overflow performance was based on the precipitation measurements results obtained from 7 January 2009 to 6 September 2014 at the pluviometric station mentioned above. The analysis takes into consideration also three-year-long precipitation sequence (2010-2012) from the rain gauge in Suków $(10 \mathrm{~km}$ from the border of the catchment) administered by IMGW (Institute of Meteorology and Water Management). It was assumed in the analyses that a rain will be regarded as precipitation when its depth reaches at least $1.3 \mathrm{~mm}$ in the time of $6 \mathrm{~h}$ (Licznar and Lomotowski 2005).

The rainfall duration at the the pluviometric station located a short distance from the border of the analysed catchment was from 10 to $2,442 \mathrm{~min}$, the dry weather period $\left(t_{w p}\right)$ varied within the range of $6 \div 36$ days, the cumulative depth of rainfall was $P_{c}=1.3 \div 45.2 \mathrm{~mm}$, whereas in the case of Suków the above rainfall characteristics were as follows: $t_{d}=15 \div 2,100$ min, $t_{w p}=6 \div 39$ days, $P_{c}=$ $=1.3 \div 14.1 \mathrm{~mm}$, respectively.

Since hitherto the analysis has not covered other factors than the effect of rainfall dynamics on the overflow discharge volume and thus disregarded the effect of rainfall variability during the rainfall event on the maximum instantaneous discharge, its duration and the percentage of the stormwater discharged through the overflow in relation to the total hydrograph volume, the performed analyses focused on 10-, 15-, and 30-minute rainfall depth characterizing the varied rainfall intensity distribution. These parameters in the case of Suków (IMGW) pluviometric station were: $P_{t d=10}=$ $=0.7 \div 15.3 \mathrm{~mm}, P_{t d=15}=0.1 \div 15.1 \mathrm{~mm}$ and $P_{t d=30}=0.1 \div 21.2 \mathrm{~mm}$, respectively, whereas in the other case the obtained values were: $P_{t d=10}=0.5 \div 14.4 \mathrm{~mm}$, $P_{t d=15}=0.2 \div 19.3 \mathrm{~mm}$ and $P_{t d=30}=$ $=0.2 \div 25.6 \mathrm{~mm}$, respectively.

\section{Hydrodynamic model}

The volume of stormwater reaching the treatment plant and drained through the emergency overflow weir was calculated using the SWMM 5.0 program (Ross- 
mann 2004, Zawilski 2010). The analyses involved the use of sequential precipitation measurement data from the years 2009-2014 obtained at the precipitation station located in the city of Kielce and three-year-long precipitation sequence from the raingauge in Suków.

The hydrological model of the catchment consists of 92 subcatchments of $0.12 \div 2.10$ ha, 200 manholes and 72 drain pipe segments. The area of subcatchments, the slope, the degree of sealing as well as the lengths, the diameters, the gradient of the pipe segments and their depth were determined on the basis of the map, the carried out field measurements and the project documentation of the structure (Butech 2003).

The computations covered calibrating the value of the flow route width $(W)$ and the depth of depression storage impervious $\left(d_{i m p}\right)$ for the adopted values of the roughness coefficient for impervious $\left(n_{\text {imp }}=0.015 \mathrm{~m}^{-1 / 3} \cdot \mathrm{s}^{-1}\right)$ and pervious $\left(n_{\text {perv }}=0.15 \mathrm{~m}^{-1 / 3} \cdot \mathrm{s}^{-1}\right)$ areas, theroughness coefficient for the walls of sewers $\left(n_{\text {sew }}=\right.$ $\left.=0.015 \mathrm{~m}^{-1 / 3} \cdot \mathrm{s}^{-1}\right)$, the maximum $\left(J_{\max }=\right.$ $\left.=90 \mathrm{~mm} \cdot \mathrm{h}^{-1}\right)$ and minimum $\left(J_{\min }=\right.$ $=15 \mathrm{~mm} \cdot \mathrm{h}^{-1}$ ) rate of infiltration into the soil, the drying rate $\left(\gamma=3 \mathrm{~h}^{-1}\right)$ and the total drying time.

The mathematical model of the stormwater treatment plant (STP) was developed basing on the field measurement results and the project documentation of the structure (Butech 2003). Due to a variable width of the overflow crest, the hydraulic model preliminarily adopted for the calculations was that for a broad-crested overflow whose discharge coefficient was determined through calibration. The figures obtained from measuring the filling level in the division chamber and the flows in the outflow storm drain were applied. The maximum stormwater levels in the division chamber and in the settling basin were defined by means of a water-level indicator (washable marker). The calibration of the discharge curve for the downpipes draining stormwater to the treatment plant was based on the figures obtained from measuring the filling level in the division chamber, in the first place for $h=0.00 \div 0.42 \mathrm{~m}$, and next for $h=$ $=0.42 \div 0.95 \mathrm{~m}$. In the second stage the preliminarily adopted value of the overflow discharge coefficient was corrected and the values of local head loss coefficients were insignificantly changed (up to $5 \%$ ) on the inlets to the downpipes in order to provide the best-fit measurement results for the simulation of the analysed division chamber within the specified range of the filling levels. The values of local resistance coefficient for piping bends, elbows, inlets and outlets were preliminarily adopted following the analysis of the hydraulic diagrams presented by Idelchik (1996). In the hydraulic calculations the absolute roughness of the pipes $k=1.5 \mathrm{~mm}$ (ATV A-110, 1988) was adopted. In the developed model of stormwater treatment plant the settling basin and the separator are defined as detention reservoirs.

The calculations performed using the SWMM allowed the determination of the volume of stormwater outflow from the catchment $\left(V_{c}\right)$, the inflow volume to the treatment plant $\left(V_{S T P}\right)$ and the overflow discharge $\left(V_{o v}\right)$. The calculations outcome were also: maximum instantaneous flow $\left(Q_{p}\right)$, the duration of its activation $\left(t_{o v}\right)$, the volume of stormwater outflow from the catchment $\left(V_{c}\right)$, the inflow volume to the treatment plant $\left(V_{S T P}\right)$ and the 
overflow discharge $\left(V_{o v}\right)$. The calculations provided also the depth of surface runoff $h=V_{c} / F$ (where: $V_{c}$ - the hydrograph volume $V_{c}=\Sigma 0.5 \cdot\left(Q_{i}+Q_{i+1}\right) \cdot \Delta t$, $F$ - the total catchment area). On the basis of those data it was possible to calculate the percentage of the stormwater volume drained through the overflow, defined as $\eta_{V}=V_{o v} / V_{c}$. This is an important parameter since it shows the volume fraction of the catchment outflow hydrograph in the stormwater reaching the treatment plants, which corresponds to the hydraulic load of the technological devices.

\section{Hydrodynamic model calibration}

The following parameters were used to evaluate the conformity of the measured and simulated catchment outflow hydrographs and the filling levels of the division chamber:

- the relation between the measured and the simulated outflow volume $\left(R_{V}\right)$ :

$$
R_{V}=\frac{V_{c(m e s)}}{V_{c(\text { sim })}}
$$

where:

$V_{c(\text { mes })}$ - the measured outflow volume $\left(\mathrm{m}^{3}\right)$;

$V_{c(\text { sim })}$ - the outflow volume calculated with the SWMM program $\left(\mathrm{m}^{3}\right)$;

- the relation between the measured and simulated peak flow $\left(R_{Q}\right)$ :

$R_{Q}=\frac{Q_{d \max (m e s)}}{Q_{d \max (\text { sim })}}$

where:

$Q_{d \max (m e s)}$ - the measured peak flow $\left(\mathrm{m}^{3} \cdot \mathrm{s}^{-1}\right)$;
$Q_{d \max (\text { sim })}$ - the peak flow calculated with the SWMM program $\left(\mathrm{m}^{3} \cdot \mathrm{s}^{-1}\right)$.

- Nash-Sutcliffe coefficient (NC):

$N C=1-\frac{\sum_{i=1}^{n}\left(Q_{i(\text { mes })}-Q_{i(\text { sim })}\right)^{2}}{\sum_{i=1}^{n}\left(Q_{i(\text { mes })}-Q_{i(\text { memes })}\right)^{2}}$

where:

$Q_{i(m e s)}$ - the measured flow intensity $\left(\mathrm{m}^{3} \cdot \mathrm{s}^{-1}\right)$

$Q_{i(\operatorname{sim})}$ - the flow intensity calculated with the SWMM program $\left(\mathrm{m}^{3} \cdot \mathrm{s}^{-1}\right)$;

$Q_{i(m e, m e s)}$ - the mean value of the calculated flow intensity $\left(\mathrm{m}^{3} \cdot \mathrm{s}^{-1}\right)$;

- the relation between the measured and simulated maximum filling levels of the division chamber $(\delta)$ :

$\delta=\frac{h_{D C(\text { mes })}}{h_{D C(\text { sim })}}$

where:

$h_{D C \text { (mes) }}$ - the maximum measured filling level of the division chamber $-\mathrm{DC}(\mathrm{m})$;

$h_{D C(\text { sim })}$ - the maximum filling level of the division chamber calculated with the SWMM program (m);

- correlation coefficient $(R)$ :

$R=\frac{\sum_{i=1}^{n}\left(h_{\text {mes }(i)}-h_{\text {me,mes }}\right) \cdot\left(h_{\text {sim(i) }}-h_{\text {messim }}\right)}{\sqrt{\sum_{i=1}^{n}\left(h_{\text {mess }(i)}-h_{\text {me,mes }}\right)^{2} \cdot \sum_{i=1}^{n}\left(h_{\text {sim }(i)}-h_{\text {messim }}\right)^{2}}}$

where:

$n$ - the total number of observations; 
$h_{m e s(i)}$ - the observed value of the stormwater division chamber filling level (m);

$h_{m e, m e s}$ - the mean measured filling level of the DC (m);

$h_{\text {sim(i) }}$ - the value of the of the stormwater DC filling level obtained as a result of the simulation with the SWMM program (m);

$h_{m e, s i m}$ - the mean calculated filling level of the DC (m).

Three-year-long measurement sequence of the flows in the cross-section closing the analysed catchment was used for the calibration of the hydrodynamic model developed for the catchment and the overflow.

\section{Analysis of the precipitation characteristics effect on the overflow performance}

Defining the impact of particular precipitation characteristics $\left(P_{t d=10}\right.$, $\left.P_{t d=15}, P_{t d=30}, P_{c}, t_{d}, t_{w p}\right)$ and the surface runoff $(h)$ on the stormwater overflow (the overflow discharge volume $\left(V_{o v}\right)$, the overflow time $\left(t_{o v}\right)$, the maximum instantaneous flow $\left(Q_{p}\right)$ and the percentage of the stormwater volume discharged through the overflow in the total hydrograph volume $\left(\eta_{V}\right)$, involved determining the correlation matrix and identifying which relationships are statistically significant for the adopted level of confidence. Prior to that, the Shapiro-Wilk test was applied to check whether the distribution of the analysed variables were similar to the normal one. In the case when the variables had a distribution similar to the normal one, the Pearson's correlation coefficient was determined, in other cases the Spearman's rank correlation coefficient was calculated.

\section{RESULTS AND DISCUSSION}

Based on the calculations performed with use of SWMM and the collected rainfall measurements (the total depth of rainfall $-P_{c}$, the duration $-t_{d}$, the outflow hydrograph volume $-V_{c}$ ) and the flows, the hydrodynamic model parameters were determined by calibration for the catchment and the stormwater overflow. This allowed the calculation of the fitting parameters for the outflow hydrographs and the division chamber filling levels for seven selected rainfall-outflow events (Table 1). The rainfall events of 8 July 2011, 15 September 2010, 30 July 2010 and 8 July 2009 were intense and accompanied by stormwater overflow discharge, whereas during the rainfalls of 31 May 2010 and 26 April 2010 no overflow discharge was recorded.

The model was then validated based on the seven rainfall events. These calculations show that the values of the parameters $R_{V}, R_{Q}, N C, \delta$ and $R$ (Table 1) in the analysed cases varied in the range of $0.85 \div 0.98 ; 0.84 \div 0.95 ; 0.75 \div 0.90$ as well as $0.85 \div 0.97$ and $0.83 \div 0.90$, respectively. It can be concluded, based on the data, that the hydrodynamic model of the catchment leads to a slight overestimation of the maximum peak flow (by $8 \%$ ) and the surface runoff volume (by $12 \%$ ), which is confirmed by the values of $R_{Q}$ and $R_{V}$. On the other hand, the analysis of the obtained values of the Nash-Sutcliffe 
coefficient (Table 1), leads to the conclusion that the variability of the simulated and measured flows is satisfactory.

On the basis of the literature review (Mrowiec 2009, Sowiński and Skotnicki 2009, Koppel et al. 2014) it can be concluded that the resulting range of $N C=$ $=0.75 \div 0.92$ indicates that the analysed hydrodynamic model has been calibrated correctly. The fitting values analysis of the stormwater overflow model $\delta$ and $R$ (Table 1) shows that the maximum instantaneous overflow discharges calculated with the SWMM model are underestimated by no more than approximately $12 \%$. Analyzing the possibility of using the SWMM model to predict the overflow performance, it was found that the obtained values of correlation coefficient $(R=0.85 \div 0.91)$ indicated a satisfactory fitting of the division chamber's filling level variability obtained from the measurement results and hydrodynamic simulations. On the basis of the model calibration through successive model executions it was concluded that the depth of depression storage of impervious surfaces and the flow route width are $d_{\text {imp }}=$ $=1.5 \mathrm{~mm}$ and $W=1.1 \cdot \mathrm{F}^{0.5}$, respec- tively. Moreover, the performed computations showed that the yield coefficient for the emergency overflow weir is 0.36 , whereas the values of local resistance coefficient at the inlet and outlet of pipelines transporting stormwater to the settling basin varied within the ranges: $0.48 \div 0.53$ and $0.95 \div 1.10$. Taking into account the calculation results it can be concluded that the SWMM model can be used for the calibration and identification of the parameters of the catchment and overflow model.

On the basis of the SWMM simulations using six-year-long observational precipitation sequences, it can be stated that the probable number of discharges in different years was as follows: 10 in 2009,15 in 2010, 18 in 2011, 21 in 2012, 22 in 2013, 30 in 2014, which gives 116 discharges in total. The obtained calculation results were used to prepare Figure 3, which depicts the variability and the occurrence frequency of the following variables in the analysed period of time: the outflow discharge volume (Fig. 3b), the maximum instantaneous flows (Fig. 3a), the discharge duration (Fig. 3c), the percentage of the outflow

TABLE 1. Rainfall event characteristics and the fitting parameters for the hydrographs and the measured and simulated filling levels of the division chamber (DC)

\begin{tabular}{|c|c|c|c|c|c|c|c|c|c|}
\hline \multirow{2}{*}{ Date } & \multicolumn{7}{|c|}{ Catchment outflow hydrograph } & \multicolumn{2}{|c|}{ DC } \\
\hline & $P_{c}(\mathrm{~mm})$ & $t_{d}(\min )$ & $q_{m e}\left(\mathrm{dm}^{3} \cdot \mathrm{ha}^{-1} \cdot \mathrm{s}^{-1}\right)$ & $V_{c}\left(\mathrm{~m}^{3}\right)$ & $R_{Q}(-)$ & $R_{V}(-)$ & $N C(-)$ & $\delta(-)$ & $R$ \\
\hline 08.07 .2011 & 8.6 & 60 & 23.89 & 1733 & 0.95 & 0.85 & 0.84 & 0.88 & 0.90 \\
\hline 15.09 .2010 & 9.2 & 286 & 5.36 & 2221 & 0.84 & 0.92 & 0.92 & 0.95 & 0.85 \\
\hline 30.07 .2010 & 12.5 & 107 & 19.47 & 1908 & 0.92 & 0.94 & 0.85 & 0.97 & 0.91 \\
\hline 08.07 .2009 & 16.5 & 270 & 10.19 & 3415 & 0.93 & 0.98 & 0.77 & 0.94 & 0.86 \\
\hline 03.07.2009 & 4.2 & 26 & 26.93 & 2133 & 0.95 & 0.96 & 0.78 & 0.96 & 0.88 \\
\hline 31.05 .2010 & 5.4 & 56 & 16.07 & 684 & 0.93 & 0.92 & 0.75 & 0.91 & 0.87 \\
\hline 26.04 .2010 & 3.6 & 92 & 6.52 & 327 & 0.90 & 0.91 & 0.84 & 0.92 & 0.90 \\
\hline
\end{tabular}


discharge volume in the total hydrograph volume of the inflow from the catchment (Fig. 3d). The hydrodynamic simulations performed for a validation set revealed that in the total number of 140 rainfall events, in 52 cases the volume of stormwater flowing into the reservoir changed from 40 to $5,189 \mathrm{~m}^{3}$ and the duration of the overflow activity for particular events was from 20 to $215 \mathrm{~min}$, the maximum instantaneous flows amounted from 0.08 to $2.11 \mathrm{~m}^{3} \cdot \mathrm{s}^{-1}$ and the fraction of the stormwater overflow discharge in the total outflow hydrograph volume from 0.04 to 0.69 .

a

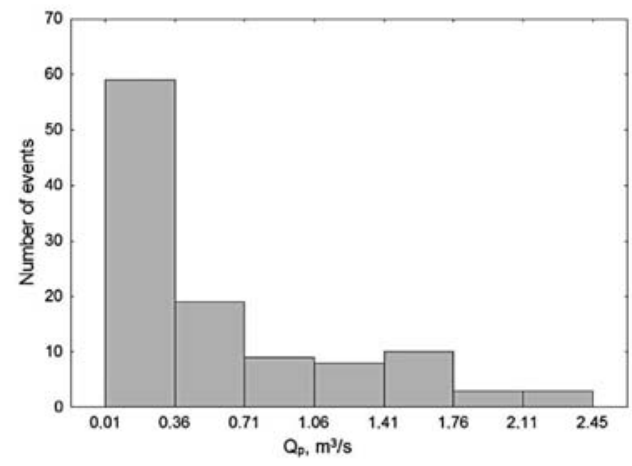

c

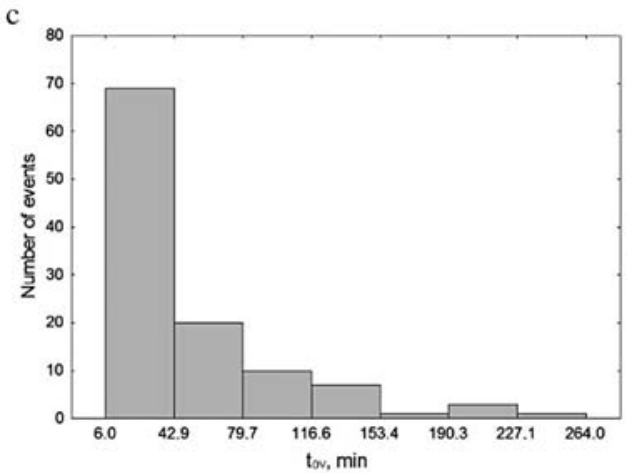

The calculations show (Fig. 3) that the discussed parameters defining the overflow operations vary to a large extent. In 79 events $(71 \%$ of the cases with the overflow discharge) the overflow discharge volume was below $V_{\text {ov } 0}=897.8 \mathrm{~m}^{3}$, and in the remaining $29 \%$ the volume was larger, not exceeding, however, $6,274.1 \mathrm{~m}^{3}$ (Fig. 3b). Figure 3a shows that in 59 events of the rainfall-runoff type (53 cases in which a discharge was reported), the maximum instantaneous flow was lower than $Q_{p_{0} 0}=$ $=0.36 \mathrm{~m}^{3} \cdot \mathrm{s}^{-1}$, whereas in $47 \%$ the flow value $Q_{p}$ o was exceeded, but was not higher than $2.45 \mathrm{~m}^{3} \cdot \mathrm{s}^{-1}$.

b

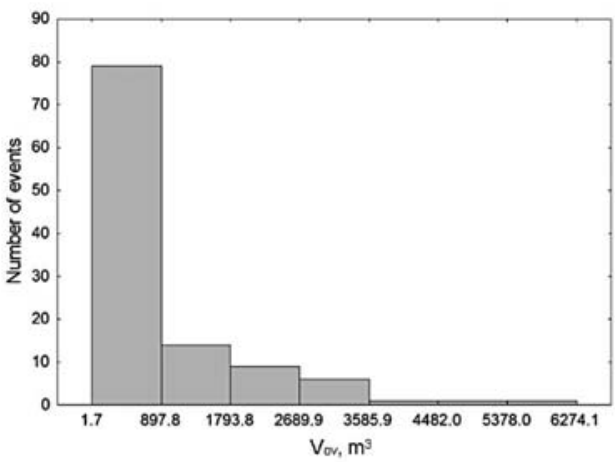

d

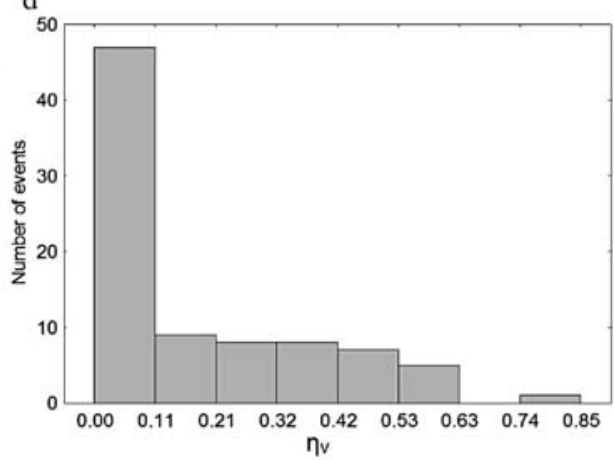

FIGURE 3. Histograms depicting the number of events: maximum instantaneous flows (a), overflow discharge volumes (b), duration times (c), the percentage of stormwater outflow directly to the receiver in the total hydrograph volume (d) 
In 69 rainfall events $(62 \%$ of the cases with a discharge) the time of the overflow discharge was not longer than $t_{o v} 0=42.9 \mathrm{~min}$, whereas in $38 \%$ of the rainfall-runoff events, the overflow activity time was shorter, but not exceeding 264 min (Fig. 3c). Figure 3d shows that in 53 events, the percentage of the overflow discharge volume in relation to the total hydrograph volume was not higher than $\eta_{V_{-} 0}=0.12$, whereas in $52 \%$ of the analysed events it exceeded $\eta_{V 0}$, and in the least favourable case it was $\bar{\eta}_{V}=0.85$.

The presented diversity (Fig. 3) is significant with regard to the evaluation of the treatment plant efficiency in the discussed period, since it shows the number of events during which the maximum load of the designed technological devices occurs. It also makes it possible to forecast the size of the load of contaminants discharged directly into the receiver, assuming the model for the stormwater quality simulation is calibrated.

In order to define the effect of a selected precipitation and surface runoff characteristics on the overflow performance, the Spearman's rank correlation matrix was calculated for $p=0.05$
(Table 2) and the Shapiro-Wilk test was performed. The test confirmed that on the level of $p=0.00001$ it is justifiable to reject the null hypothesis and to claim that the analysed variables do not have a normal distribution.

The calculated matrix reveals the lack of the statistically significant effect of the dry of weather period $\left(t_{w p}\right)$ on the discharge volume $\left(V_{o v}\right)$, the maximum instantaneous flow $\left(Q_{p}\right)$ and the percentage of the overflow discharge volume $\left(V_{o v}\right)$ in relation to the total hydrograph volume $\left(V_{c}\right)$. One can observe, however, a statistically weak significant relation between the discharge duration $\left(t_{o v}\right)$, and the duration of the dry weather period $\left(t_{w p}\right)$ and a strong relation between the discharge duration $\left(t_{o v}\right)$ and the depth of the surface runoff $(h)$ and the cumulative rainfall depth $\left(P_{c}\right)$. On the basis of the performed calculations (Table 2) it was found that there was a strong relation between the overflow discharge volume $\left(V_{o v}\right)$, the percentage of the overflow discharge volume in relation to the total inflow hydrograph volume and the maximum temporary overflow discharge $\left(Q_{p}\right)$ and the maximum 10-, 15- and 30-minute

TABLE 2. The Spearman's matrix of rank correlations between the particular characteristics of the overflow, the rainfalls and the surface runoff

\begin{tabular}{|l|c|c|c|c|}
\hline Variable & $t_{o v}$ & $V_{o v}$ & $Q_{p}$ & $\eta_{V}$ \\
\hline$h$ & 0.806 & 0.663 & 0.492 & 0.350 \\
\hline$P_{c}$ & 0.811 & 0.596 & 0.422 & 0.296 \\
\hline$P_{t d=10}$ & 0.087 & 0.721 & 0.783 & 0.784 \\
\hline$P_{t d=15}$ & 0.309 & 0.758 & 0.851 & 0.821 \\
\hline$P_{t d=30}$ & 0.534 & 0.881 & 0.897 & 0.859 \\
\hline$t_{d}$ & 0.429 & $0.015^{*}$ & $-0.149^{*}$ & -0.271 \\
\hline$t_{w p}$ & -0.241 & $-0.184^{*}$ & $-0.163^{*}$ & $0.097^{*}$ \\
\hline$q_{m e}$ & $0.096^{*}$ & 0.510 & 0.596 & 0.651 \\
\hline
\end{tabular}

* Significance at $p=0.05$. 
rainfall depth $\left(P_{t d=10}, P_{t d=15}, P_{t d=30}\right)$. Identical analyses were performed also when the relation between $P_{c}$ and $t_{d}$ was expressed as the mean rain intensity $\left(q_{m e}=P_{c} \cdot t_{d}{ }^{-1}\right)$. The calculation revealed a medium-strong relation between $q_{\text {avg }}$ and the parameters depicting the stormwater overflow performance: $V_{o v}, Q_{p}$ and $\eta_{V}$.

The relations presented in Figures 4 and $5 t_{o v}=f\left(P_{c}\right), V_{o v}=f\left(P_{t d=30}\right), Q_{p}=$ $=f\left(P_{t d=30}\right)$ and $\eta_{V}=f\left(P_{t d=30}\right)$ were determined based on the correlation matrix (Table 2), and using the hitherto research results of Zawilski et al. (2014); the following regression relations depicting the effect of the rainfall event dynamics on the performance parameters of the stormwater overflow located on the inflow to the treatment plant were given:

- discharge duration $\left(t_{o v}\right)$ :

$$
t_{o v}=4.170( \pm 0.418) \cdot P_{c}
$$

- discharge volume $\left(V_{o v}\right)$ :

$$
\begin{aligned}
& V_{o v}=241.017( \pm 18.857) \cdot P_{t d=30}- \\
& -434.260( \pm 96.678)
\end{aligned}
$$

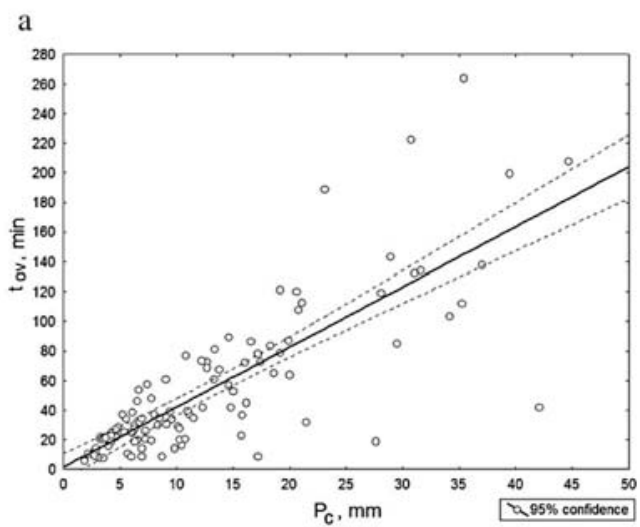

- maximum instantaneous flow $\left(Q_{p}\right)$ :

$$
Q_{p}=0.114( \pm 0.008) \cdot P_{t d=30}-
$$

$-0.140( \pm 0.052)$

- percentage of the stormwater discharge volume $-V_{z}$, in relation to the total hydrograph volume $-V_{c}\left(\eta_{V}\right)$ :

$$
\begin{aligned}
& \eta_{V}=0.040( \pm 0.004) \cdot P_{t d=30}+ \\
& +0.010( \pm 0.026)
\end{aligned}
$$

Using the data from the validation set, the values $t_{o v}, V_{o v}, Q_{p}$ and $\eta_{V}$ were calculated from the formulas (6)-(9), and then compared with the hydrodynamic simulations results. The correlation coefficient $(r)$ was determined, in the case of $t_{o v}$ the coefficient $r$ was equal to 0.751 , for $V_{o v}$ it amounted to 0.857 and for $Q_{p}$ to 0.912 , whereas for $\eta_{V}$ correlation coefficient was equal to 0.863 . On this basis, it can be concluded that the resulting relations (6)-(9) are correct and can be used in practib

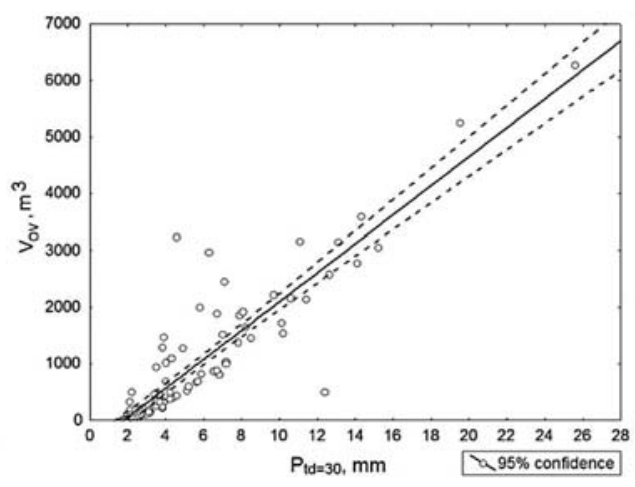

FIGURE 4. The effect of: (a) the total rainfall depth $\left(P_{c}\right)$ on the discharge duration $\left(t_{o v}\right)$, (b) 30-minute rainfall depth $\left(P_{t d=30}\right)$ on the volume of the stormwater discharged directly to the receiver $\left(V_{o v}\right)$ 

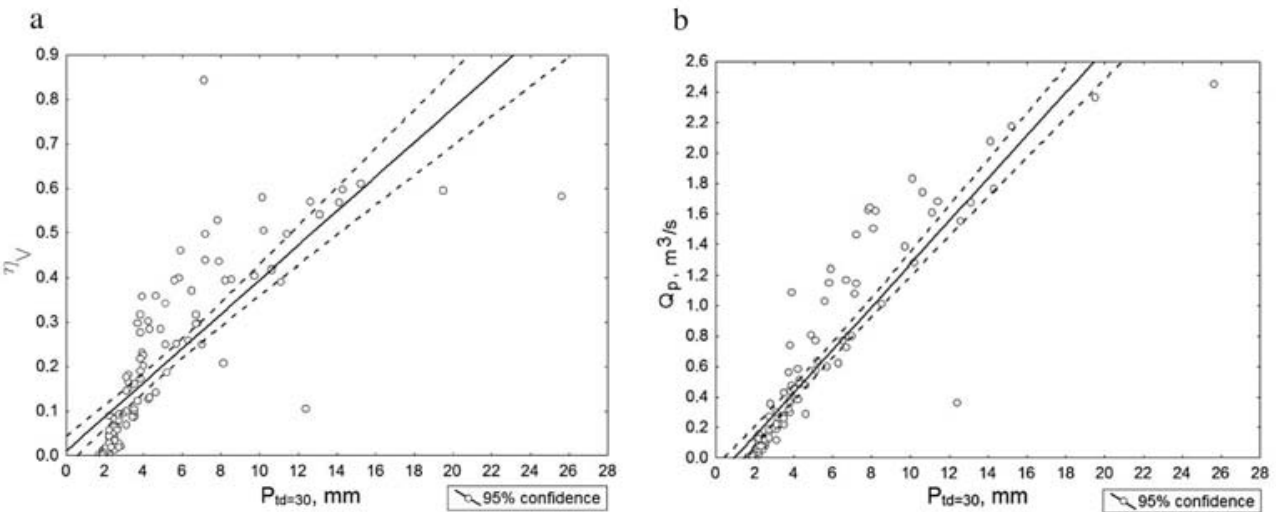

FIGURE 5. The effect of 30-minute rainfall depth $\left(P_{t d=30}\right)$ on: (a) fraction of the overflow discharge volume $\left(V_{o v}\right)$ in relation to the total volume $\left(V_{c}\right)$, (b) instantaneous runoff discharged directly to the receiver $\left(Q_{p}\right)$

cal analyses. The obtained values of the correlation coefficient $r=0.7315-$ -0.9143 for the formulas (6)-(9) showed, that these equations do not take into account all the parameters of the surface runoff and the rainfall characteristics.

The application of the multiple regression for the determination of $t_{o v}, Q_{p}$, $V_{o v}$ and $\eta_{V}$ in order to increase the fitting of the measured results to the calculated ones was studied as well. It was found that the variables $\left(t_{d}, P_{c}, P_{t d=10}, P_{t d=15}\right)$ taken into account in the analysed relations were not statistically significant in most cases.

In order to determine which parameter describing the rainfall has the most significant effect on the stormwater overflow performance, a simulation of the overflow operation was performed in the SWMM program for two selected rainfall events. The selected events took place on 10 June $2009\left(P_{c}=5.1 \mathrm{~mm}\right.$, $\left.t_{d}=70 \mathrm{~min}\right)$ and $15 \mathrm{July} 2011\left(P_{c}=\right.$ $=5.5 \mathrm{~mm}, t_{d}=38 \mathrm{~min}$ ) with a similar total rainfall depth, but a different rain- fall intensity distribution; the dimensionless cumulative rainfall curves for the analysed rainfall $P / P_{c}=f\left(t / t_{d}\right)$ are presented in Figure 6.

Figure 6 shows that the rainfall intensity distribution in the rainfall event on 15 July 2011 is different than on 10 June 2009. In the first case (15 July 2011), the rainfall height from the beginning $(P)$ after the time $0.3 \cdot t / t_{d}$ amounted to $30 \%$ of the total rainfall depth $\left(P_{c}\right)$, and for $0.6 \cdot t / t_{d}$ it was equal to $0.8 \cdot P / P_{c}$. In the second case (10 June 2009) the cumulative rainfall height from the beginning of the event after the time $0.3 \cdot t / t_{d}$ amounted to $10 \%$ of $P_{c}$, and after $0.60 \cdot t / t_{d}$ it was equal to $36 \%$ of the total rainfall depth. On this basis it can be concluded, that the rainfall of 10 June 2009 is much more intensive than the event of 15 July 2011.

Figure 7 shows the variability of the rate of stormwater reaching the treatment plant $\left(Q_{S T P}\right)$ and discharged through the stormwater overflow $\left(Q_{p}\right)$ for two rainfall events of 10 June 2009 and 15 July 2011. The data presented in Figure 7 show that 


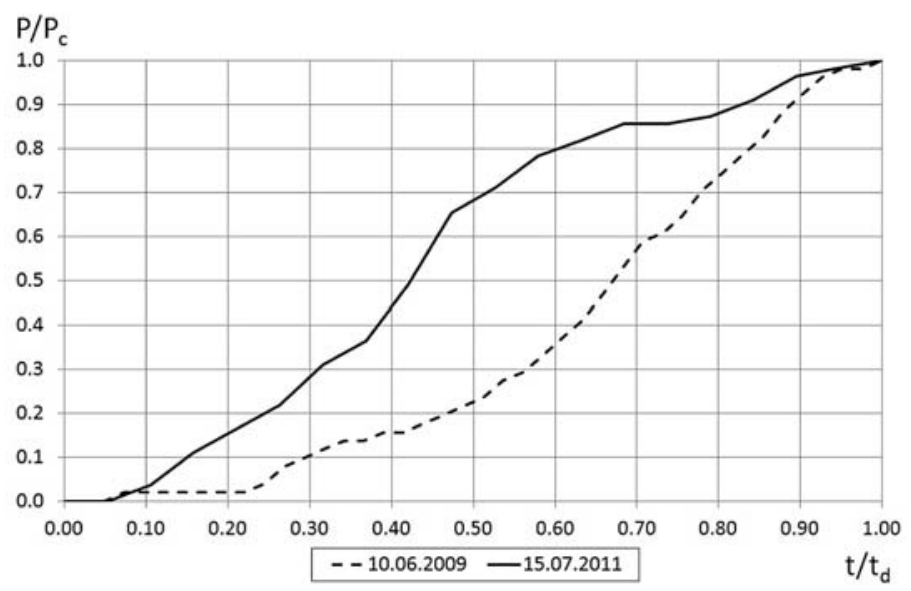

FIGURE 6. Dimensionless cumulative rainfall curves $P / P_{c}=f\left(t / t_{d}\right)$ for selected rainfall events, where: $t$ - duration time from the beginning of the rainfall, $P$ - the rainfall depth from the beginning of the rainfall; the remaining designations as above
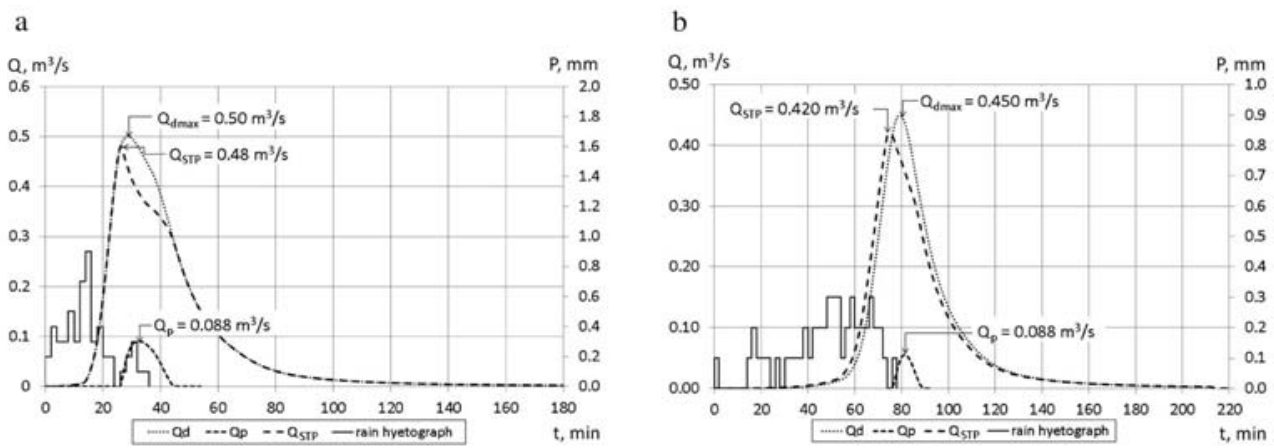

FIGURE 7. Variability of the rate of stormwater outflow from the catchment, stormwater reaching the treatment plant and the overflow discharge in the rainfall event: (a) 15 July 2011, (b) 10 June 2009, where: $Q_{d}$-the rate of stormwater outflow from the catchment through the Si9 storm drain, $Q_{S T P}-$ maximum rate of the flow reaching the treatment plant, $Q_{d \max }$ - peak flow during a rainfall event

despite only slight differences in the total rainfall depth $(7.3 \%)$, the stormwater outflow operated differently during the analysed events. In the first case on 15 July 2011 (Fig. 7a) the maximum instantaneous stormwater overflow discharge and the discharge duration time were, respectively $Q_{p}=0.088 \mathrm{~m}^{3} \cdot \mathrm{s}^{-1}$ and $t_{o v}=22 \mathrm{~min}$, and during the rainfall on 10 June 2009 (Fig. 7b): $Q_{p}=$ $=0.055 \mathrm{~m}^{3} \cdot \mathrm{s}^{-1}, t_{o v}=14 \mathrm{~min}$.
Significant differences in the distribution of rain intensity (Fig. 6) are reflected in the time of water rising, maximum peak flow, the variability plot of the catchment outflow hydrograph (Fig. 7), which affected the time of the filling level in the division chamber exceeding 0.42 (the height of the overflow edge) and the rate variability of the stormwater overflow discharge directly to the receiver. 


\section{CONCLUSIONS}

The performed calculations revealed that the mean rainfall intensity $\left(q_{m e}\right)$ is not a representative parameter to evaluate the performance of the storm overflow located on the inflow to the stormwater treatment plant. This is due to the fact that averaging the variable intensity of rainfall in time does not reflect the dynamics of rainfall in the course of its duration, which significantly determines the operation of the stormwater overflow. The statistical analyzes of the urban catchment under consideration showed that the 30-minute rainfall depth have a significant impact on the volume of discharge, the maximum instantaneous flow discharged through the outflow and the percentage of stormwater volume related to the total volume of the inflow hydrograph from the catchment. The calculations revealed a slight impact of the dry weather period on the duration of the stormwater overflow discharge in the analyzed catchment area. In addition, it was found that the dry weather period did not have any statistically significant effect on the discharge volume, the maximum instantaneous flow discharged through the overflow and the percentage of the volume of stormwater overflow discharge in relation to the total volume of the inflow hydrograph from the catchment. In modelling the load of contaminants transported from the catchment to the receiver the dry weather period has a significant effect on the amount of contaminants collected on the surface of the catchment and cannot be disregarded in computations. Taking into account the results of the statistical and hydraulic analyses, applied to study the distribution chamber, it was found that the stormwater inflow variability in time, determined by the rainfall intensity distribution, that has the greatest impact on the storm overflow performance.

The statistical analyses demonstrated that the regression relations developed in the study can be applied to assess the performance of the emergency overflow weir. They provide a solution, which is an alternative for hydrodynamic models, and significantly reduce computational effort at the stage of analyzing the performance of facilities located in sewer systems. Owing to a high level of agreement between the computation results and simulations performed using the SWMM programme, the obtained calculation formulas can be applied by technical supervisors and persons managing the sewer system.

Moreover, in order to verify the formulas mentioned above, it is advisable to conduct further analyses on other urban catchments with varied physical-geographic characteristics.

\section{REFERENCES}

ANDRÉS-DOMÉNECH I., SEGURA J.B. 2008: Multivariate rainfall distributions for stormwater detention tank sizing using probabilistic and single - event approaches. A comparison between norther and eastern Spain. $11^{\text {th }}$ International Conference on Urban Drainage, Edinburgh, Scotland.

ATV DVWK A-110, 1988: Richtlinien für die hydraulische Dimensionierung und den Leitstungsnachweis von Abwasserkanälen und-Leitungen, GFA, Hennef.

ATV DVWK A-128, 1992: Richtlinien für die Bemessung und Gestaltung von Regenentlastungsanlagen in Mischwasserkanälen, GFA, Hennef. 
BACH P.M., McCARTHY D.T., DELETIC A. 2010: Redefining the stormwater first flush phenomenon. Water Research. 44, 2478-2498.

BERTRAND-KRAJEWSKI J.L., CHEBBO G., SAGET A. 1998: Distribution of pollutant mass vs volume in stormwater discharges and the first flush phenomenon. Water Research. 32, 2341-2356.

BUTECH Sp. z o.o. 2003: Construction of stormwater treatment on the collector Si9, Projekt budowlany. Kielce (in Polish).

BĄK Ł., GÓRSKI J., GÓRSKA K., SZELĄG B. 2012: Suspended Solids and Heavy Metals Content of Selected Rainwater Waves in Urban Catchment Area: A Case Study. Ochrona Środowiska 34 (2), 49-52.

CAMBEZ M.J., PINHO J., DAVID L.M. 2008: Using SWMM in continuous modeling of stormwater hydraulics and quality. $11^{\text {th }}$ International Conference on Urban Drainage, Edinburgh, Scotland.

CZEMIEL-BERNDTSSON J. 2014: Storm water quality of first flush urban runoff in relation to different traffic characteristics. Urban Water Journal. 11 (4), 284 - 296.

DĄBKOWSKI S.L., GÓRSKA K., GÓRSKI J., SZELĄG B. 2010: Introductory results of examining precipitation sewage in one of Kielce channels. Gaz, Woda i Technika Sanitarna 6, 20-24 (in Polish).

DĄBROWSKI W. 2004: The influence of sewer networks on the environment. Wydawnictwo Politechniki Krakowskiej, Kraków (in Polish).

DĄBROWSKI W. 2007: Estimating, computing and measuring multiplication factors for the working of storm overfalls. Gaz, Woda i Technika Sanitarna 11, 1921 (in Polish).

DELETIC A. 1998: The first flush load of urban surface runoff. Water Research. 32, 2462-2470.

DEMPSEY P., EADON A., MORRIS G. 1997: SIMPOL a simplified urban pollution modeling tool. Water Science and Technology 36 (8-9), 83-88.
FIDALA-SZOPE M., SAWICKA-SIARKIEWICZ H., KOCZYK A. 1999: Protection of surface waters from discharges of stormwater from wastewater system. Handbook, Instytut Ochrony Środowiska, Warszawa (in Polish).

GARBARCZYK K., TUZ P.K. 2003: The influence of the development of an urban drainage area on the stormwater quality. In: Environmental Engineering Studies. Polish Research on the way to the EU. L. Pawłowski, M.R. Dudzinska, A. Pawłowski (Eds) Kluwer Academic/ /Plenum Publishers, New York, 81-86.

IDELCHIK I.E. 1996: Handbook of Hydraulic Resistance. $3^{\text {rd }}$ edition. Begeli House, New York.

KOPPEL T., VASSILJEV A., PUUST R., LAANEARU J. 2014: Modelling of stormwater discharge and quality in urban area. International Journal of Ecological Science and Environmental Engineering 1 (3), 80-90.

KREBS G., KOKKONEN T., VALTANEN M., KOIVUSALO H., SETÄLÄ H. 2013: A high resolution application of a stormwater management model (SWMM) using genetic parameter optimization. $U r$ ban Water Journal 10 (6), 394-410.

LICZNAR P., ŁOMOTOWSKI J. 2005: Analysis of Average Design Storm Intensity for the City of Wrocław. Ochrona Środowiska 27 (1), 29-34 (in Polish).

MADSEN H. 2003: Parameter estimation in distributed hydrological catchment modelling using automatic calibration with multiple objectives. Advance in Water Resources 26, 205-216.

MROWIEC M. 2009: Efficient dimensioning and dynamics regulation of sewage reservoirs. Wydawnictwo Politechniki Częstochowskiej, Częstochowa (in Polish).

NEWCOMBE C.P., JENSEN J.O. 1996: Channel suspended solids and fisheries: a synthesis for quantitative assessment of risk and impact. North American Journal of Fisheries Management 16 (4), 693-727 . 
PAOLA F., MARTINO G. 2013: Stormwater Tank Performance: Design and Management Criteria for Capture Tanks Using a Continuous Simulation and a SemiProbabilistic Analytical Approach. Water. 5 (4), 1699-1711.

ROSSMANN L.A. 2004: Storm Water Management Model, user's manual. Ver. 5.0. National Risk Management Research Laboratory Office of Research and Development. Cincinnati. U.S. Environmental Protection Agency.

SKOTNICKI M., SOWIŃSKI M. 2009: Verification of subcatchment hydraulic width evaluation method exemplified by real urban catchment. Prace Naukowe Politechniki Warszawskiej. Inżynieria Środowiska 57, 27-43 (in Polish).

SZELĄG B., GÓRSKI J. BĄK Ł., GÓRSKA K. 2013: Application of SWMM software to the modelling of stormwater quantity and quality on the example of urbanised catchment in Kielce. Ecological Chemistry and Engineering A. 20 (11), 1305-1316.

THORNDAHL S. 2008: Stochastic long term modelling of a drainage system with estimation of return period uncertainty. $11^{\text {th }}$ International Conference on Urban Drainage, Edinburgh, Scotland, UK.

VAES G., BERLAMONT J. 1999: Emission predictions with a multi - linear reservoir model. Water Science and Technology 39 (2), 9-16.

ZAGHLOUL N.A., KIEFA M.A. 2001: Neural network solution of inverse parameters used in the sensitivity - calibration analyses of the SWMM model simulations. Advances in Engineering Software 32, 587-595.

ZAWILSKI M. 2010: Integration of urbanized catchment area in simulation of precipitation sewage run-off. $G a z$, Woda i Technika Sanitarna 6, 28-32 (in Polish).
ZAWILSKI M., BRZEZIŃSKA A., SAKSON G. 2014: Assessment of combined sewer overflow performance on the basis of areal rainfall monitoring. $13^{\text {th }}$ International Conference on Urban Drainage. Urban Drainage in the Context of Integrated Urban Water Management: A Bridge between Developed and Developing Countries.

Streszczenie: Ocena wpływu dynamiki opadu deszczu na działanie przelewu burzowego. W prezentowanej pracy przeanalizowano wpływ charakterystykopadowych(całkowitaorazmaksymalna 15i 30-minutowa wielkość opadu deszczu, czas jego trwania, okres bezdeszczowy) na działanie przelewu zlokalizowanego na dopływie do oczyszczalni ścieków deszczowych. Do analiz tych wykorzystano wyniki obliczeń numerycznych hydrogramów odpływu wykonane w programie SWMM (Storm Water Management Model) na podstawie sześcioletnich ciągów pomiarowych opadów deszczów. Otrzymane wyniki symulacji pozwoliły na przeprowadzenie analiz statystycznych, które wykazały, że w analizowanej zlewni na objętość zrzutu ścieków, maksymalny chwilowy przepływ i udział objętości ścieków odprowadzanych przelewem burzowym w odniesieniu do całkowitej objętości hydrogramu dopływu ze zlewni ma wpływ maksymalna 30-minutowa wielkość opadu deszczu, z kolei na czas trwania zrzutu wpływa grubość warstwy odpływowej ze zlewni. Na podstawie uzyskanych wyników obliczeń statystycznych oraz hydraulicznych w rozpatrywanej zlewni wykazano, że największy wpływ na funkcjonowanie przelewu ma rozkład natężenia opadu deszczu.

\section{MS received April 2016}

\author{
Author's address: \\ Bartosz Szeląg \\ Wydział Inżynierii Środowiska, Geomatyki \\ i Energetyki \\ Politechnika Świętokrzyska \\ al. Tysiąclecia Państwa Polskiego 7 \\ 25-314 Kielce, Poland \\ e-mail: bszelag@tu.kielce.pl
}

